\title{
A Quantitative Approach to Estimate both Essential and Non-essential Elements in Some Commercial Samples of Triphala churna by using WD-XRF Spectrometry
}

\author{
Venkata Siva Satyanarayana Kantamreddi ${ }^{1 *}$, V. Thirumala Veni ${ }^{1}$ and G. Y. S. K. Swamy ${ }^{2}$
}

Venkata Siva Satyanarayana Kantamreddi ${ }^{*}$, V. Thirumala Veni ${ }^{1}$ and G. Y. S. K. Swamy ${ }^{2}$

'Centre for Chemical Analysis, Central Research Laboratory, GIT, GITAM University, Visakhapatnam, Andhra Pradesh, INDIA.

${ }^{2}$ Laboratory of X-ray Crystallography, Indian Institute of Chemical Technology, CSIR, Hyderabad, Telangana, INDIA.

\section{Correspondence}

Venkata Siva Satyanarayana Kantamreddi,

Assistant Professor of Chemistry, Centre for Chemical Analysis, Central Research Laboratory, GIT, GITAM University, Visakhapatnam, Andhra Pradesh, INDIA. Phone no: +91-9866787845/ 9703945669

E-mail: vssnk@yahoo.com, vssnk@ gitam.edu, kantamreddi@gmail.com

History

- Submission Date: 12-02-2017;

- Review completed: 05-03-2017

- Accepted Date: 08-03-2017

DOI : 10.5530/pj.2017.3.64

Article Available online

http://www.phcogj.com/v9/i3

Copyright

(C) 2017 Phcog.Net. This is an openaccess article distributed under the terms of the Creative Commons Attribution 4.0 International license.

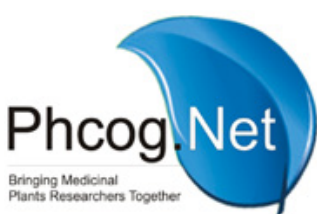

\begin{abstract}
Introduction: The need for quality control of herbal drugs is in demand in order to ensure the purity, safety and efficacy of herbal products. A total of 19 elements including essential and non-essential elements were characterized in five commercial samples of Triphala churna using WD-XRF spectrometry. Method: The WD-XRF method was validated for each element by a pre-calibrated program using five Chinese certified reference materials of vegetable standards (NCS ZC73012, NCS ZC73013, NCS ZC73017, NCS ZC85006 and NCS DC73348).

Results: The following elements were detected in all the samples out of 19 elements tested with increasing order of concentrations (mg/kg): $\mathrm{Cr}(3)<\mathrm{Cu}(7)<\mathrm{Ba}(24)<\mathrm{Zn}(31)<\mathrm{Pb}(46)<\mathrm{Mn}(57)<\mathrm{S}(700)<\mathrm{Na}(1064)$ $<\mathrm{Mg}(1250)<\mathrm{Fe}(1329)<\mathrm{P}(1400)<\mathrm{Cl}(2960)<\mathrm{Ca}(3110)<\mathrm{Si}(4350)<\mathrm{K}(15130)$. Lead $(41-46 \mathrm{mg} / \mathrm{kg})$, a nonessential element was found above its PDE limit ( $\leq 10 \mathrm{mg} / \mathrm{kg}$ ). Conclusion: WD-XRF method was found simple, rapid, reliable and non-destructive technique to investigate the elemental concentrations in herbal drugs. Key words: Elemental analysis, WD-XRF, ICP-MS, Triphala churna, Ayurveda, ISM
\end{abstract}

\section{INTRODUCTION}

Ayurvedic medicines are one of the important ancient medical systems of India. About $80 \%$ of the world population still primarily rely on herbal drugs. ${ }^{1}$ In India, Ayurvedic medicines were widely considered due to affordability and availability in local markets. Also, the demand for Ayurveda drugs in Western market has increased tremendously which draw attention to the need of quality of Ayurvedic products. Especially, the presence of heavy metals at high concentrations in these drugs are potentially harmful to consumers and causing severe adverse health effects. Hence, the screening of these herbal drugs is given preference in scientific studies and the WHO in number of resolutions has emphasized the need of quality control of plant products by using modern techniques and suitable analytical methods. ${ }^{2}$ Therefore, the present study was focused to carry out to analyse essential and non-essential elements using WD-XRF spectrometry in five commercially important Triphala churna drugs. Triphala churna is a mixture of three dried fruits (Haritaki, Bibhitaki and Amalaki) in equal proportions (1:1:1) and a variety of therapeutic applications have been described in ISM. ${ }^{3}$

\section{MATERIALS AND METHODS}

\section{Sample collection}

Triphala churna drugs were procured from local registered Ayurvedic pharmacies at Visakhapatnam, India. The batch number, date of manufacture and date of expiry are recorded and kept available in the Centre for Chemical Analysis, Central Research Laboratory, GITAM University, Visakhapatnam, India. The brand names were blinded and coded in sequential order i.e. TPC1, TPC2, TPC3, TPC4 and TPC5.

\section{Experimental and Instrumental Details}

Pellets of each drug sample and standard were made by taking three grams of powder sample in an aluminum cup and pressing using a hydraulic press (HERZOG, TP40/2D) at 15 tons to obtain a disc shape with $40 \mathrm{~mm}$ diameter. These pellets were subjected to WD-XRF spectrometer and characterized the elemental composition as described by Swamy and Sivanarayanan (2014). ${ }^{4}$

\section{RESULTS AND DISCUSSION}

In the present study, the levels of 19 essential and non-essential elements such as $\mathrm{Na}, \mathrm{Mg}, \mathrm{Al}, \mathrm{Si}, \mathrm{P}, \mathrm{S}$, $\mathrm{Cl}, \mathrm{K}, \mathrm{Ca}, \mathrm{Cr}, \mathrm{Mn}, \mathrm{Fe}, \mathrm{Cu}, \mathrm{Zn}, \mathrm{As}, \mathrm{Ba}, \mathrm{Cd}, \mathrm{Hg}$ and $\mathrm{Pb}$ were determined using WD-XRF spectrometry in five samples of Triphala churna are summarized in Table 1 and they are the mean of three replicates. The WD-XRF method was validated for each element and good agreements were achieved between present values and published data. ${ }^{4}$ The available specific standards for few trace elements $(\mathrm{Pb} \leq 10 \mathrm{ppm}$, $\mathrm{Cd} \leq 0.3 \mathrm{ppm}$, As $\leq 10 \mathrm{ppm}$ and $\mathrm{Hg} \leq 1 \mathrm{ppm}$ ) by $\mathrm{WHO}^{5}$ and tolerance limits of elements in food or

Cite this article: Kantamreddi VSS, Veni VT, Swamy GYSK. A Quantitative Approach to Estimate both Essential and Non-essential Elements in Some Commercial Samples of Triphala churna by using WD-XRF Spectrometry. Pharmacogn J. 2017;9(3):378-81 
dietary intake published by $\mathrm{CEC}^{6}$ are considered for quality regulation of Ayurvedic drugs tested in this study (Table 1).

\section{Interpretation of WD-XRF data}

Out of 19 elements analysed, $\mathrm{Na}, \mathrm{K}, \mathrm{Mg}, \mathrm{Ca}, \mathrm{P}, \mathrm{S}$ and $\mathrm{Cl}$ are essential nutrients and they were present in substantial quantities in all remedies and most of them were within tolerable upper intake level (Table 1). Elements such as $\mathrm{Ba}, \mathrm{Cr}, \mathrm{Cu}, \mathrm{Al}, \mathrm{Mn}, \mathrm{Fe}, \mathrm{Zn}$ and $\mathrm{Si}$ are considered as micronutrients and exhibit relatively low toxicity with high PDE. ${ }^{7}$ The concentration of 'Ba' in the present study was ranged from 20 to $24 \mathrm{mg} / \mathrm{kg}$ and it was within the permissible limits according to WHO guidelines (2004) i.e. the suggested mean daily intake of Ba from food, water and air is about $100 \mathrm{mg} / \mathrm{kg} .{ }^{8}$ Trivalent $\mathrm{Cr}$ has a low level of toxicity at high concentrations, but, hexavalent $\mathrm{Cr}$ is more toxic and causes renal and hepatic necrosis and growth retardation. ${ }^{6}$ In the present study, Cr was found to be present in all samples ranging from 1 to $3 \mathrm{mg} / \mathrm{kg}$, which is below the PDE limit i.e. $15 \mathrm{mg} / \mathrm{kg}$ as per USP guidelines (2009). ${ }^{9} \mathrm{In}$ all the samples, $\mathrm{Cu}$ was detected within PDE limit with concentration between 5 to $7 \mathrm{mg} / \mathrm{kg}$ and $\mathrm{Zn}$ was ranged 27 to $31 \mathrm{mg} / \mathrm{kg}$ which is about 30 times lesser than the recommended PDE limit by CEC (Table 1). The concentration of ' $\mathrm{Fe}$ ' in the present study was found within PDE limit in all the samples except TPC1 (1329 mg/kg, Table 1). The excess iron levels in the body can damages cells in the heart and liver which can cause cancer, diabetes, coma, metabolic acidosis, liver failure, cardiac failure, circulatory shock and long-term organ damages. ${ }^{10}$ An excess of Mn can lead to poor iron absorption and its deficiency can cause poor bone formation, affect fertility and ability of blood to clot. ${ }^{10}$ In the present study, Mn was found below the PDE limit in all the samples within the range of 30 to $57 \mathrm{mg} / \mathrm{kg}$ (Table 1). Aluminum intake even in small amounts may lead to bio-accumulation in consumer's body, which is so difficult to get-rid-off and further, cumulative $\mathrm{Al}$ in the body can reduce the absorption of a number of elements including essential elements $\mathrm{Fe}$, $\mathrm{P}, \mathrm{Ca}$, etc. ${ }^{10,11}$ In the present study, $\mathrm{Al}$ was detected in all the samples within the range of 362 to $1140 \mathrm{mg} / \mathrm{kg}$. Silicon was ranged from 1590 to
$4350 \mathrm{mg} / \mathrm{kg}$, an essential mineral required for human body to grow and maintain strong bones, hair, fingernails, connective tissues, skin, blood vessels and healthy artery walls. ${ }^{10,11}$ It helps to counter the effects of high accumulation of $\mathrm{Al}$ in the body, but, an excess of Si may cause irreversible kidney damage.

The other elements that are analyzed, $\mathrm{As}, \mathrm{Cd}, \mathrm{Hg}$ and $\mathrm{Pb}$ are not useful role in human physiology and therefore considered to be non-essential elements. Of these, presence of $\mathrm{Pb}$ was detected in all market samples tested in the present study with a concentration range of $41-46 \mathrm{mg} / \mathrm{kg}$ (Table 1), which is almost 4 folds higher than its PDE $(\leq 10 \mathrm{mg} / \mathrm{kg})$. In fact, $\mathrm{Pb}$ existence in herbal drugs above its permissible limit is predictable and reported in many earlier studies. However, high dose of ' $\mathrm{Pb}$ ' detected in current study in all samples may cause harmful health effects ${ }^{12}$ and alarming the safety concern of these herbal products. As, Cd and $\mathrm{Hg}$ were not detected due to they maybe present below its detection limit of XRF and in such cases, XRF should be used in conjunction with a more sensitive technique, AAS / ICP.

\section{Comparison of XRF data with ICP Data}

The WD-XRF technique has adequate sensitivity to determine essential as well as trace elements and was well proved in earlier studies. ${ }^{4}$ However, the results obtained in the present study by WD-XRF spectrometry were cross checked with available ICP-MS data (Table 2). ${ }^{3}$ The $\mathrm{Cu}$ mean values determined by the WD-XRF method was slightly higher than that determined by the ICP-MS method with good RSD (3-28\%) and only TPC1 sample was noticed with a higher ICP value with $28 \%$ RSD. A significant difference was observed for $\mathrm{Zn}$ i.e. almost two fold higher XRF values were noticed when compared with ICP data with $32-40 \%$ RSD. Agreement, typically 22-50\% (RSD) was noticed between methods WDXRF and ICP-MS for Cr. The mean values determined by the WD-XRF method was noticed to be slightly higher for elements $\mathrm{Ba}, \mathrm{Ca}, \mathrm{Fe}, \mathrm{K}, \mathrm{Mg}$, $\mathrm{Mn}, \mathrm{Na}$ when compared with reported ICP-MS data and they are close to each other with good agreement i.e. RSD (\%), 19-25, 8-10, 12-19, 4-12, $14-17,16-20$ and $22-25$, respectively. These variations in elemental con-

Table 1: Levels of elements in various Triphala Churna drugs by WD-XRF

\begin{tabular}{|c|c|c|c|c|c|c|c|c|c|}
\hline \multirow{2}{*}{$\begin{array}{l}\text { Elements } \\
(\mathrm{mg} / \mathrm{kg})\end{array}$} & \multicolumn{2}{|c|}{ PDE / UL } & \multicolumn{5}{|c|}{ Triphala Churna } & \multirow{2}{*}{ Range } & \multirow{2}{*}{ LLD } \\
\hline & AYUSH & CEC & TPC 1 & TPC 2 & TPC3 & TPC 4 & TPC 5 & & \\
\hline $\mathrm{Pb}$ & $\leq 10$ & 3.0 & 41 & 46 & 43 & 42 & 43 & $41-46$ & $<2$ \\
\hline $\mathrm{Ba}$ & NA & NA & 24 & 20 & 20 & 21 & 20 & $20-24$ & 2 \\
\hline $\mathrm{Al}$ & NA & NA & 1140 & 362 & 577 & 547 & 561 & $362-1140$ & 5 \\
\hline $\mathrm{Ca}$ & NA & 70000 & 2930 & 3000 & 3030 & 2130 & 3110 & $2130-3110$ & 5 \\
\hline $\mathrm{Cr}$ & NA & NA & 2 & 3 & 2 & 2 & 1 & $1-3$ & $<2$ \\
\hline $\mathrm{Cu}$ & NA & 110 & 5 & 7 & 6 & 5 & 5 & $5-7$ & 2 \\
\hline $\mathrm{Fe}$ & NA & 900 & 1329 & 465 & 792 & 869 & 918 & $465-1329$ & 2 \\
\hline K & NA & 310000 & 14760 & 13180 & 14560 & 15130 & 13330 & $13180-15130$ & 5 \\
\hline $\mathrm{Mg}$ & NA & 50000 & 1250 & 1220 & 1210 & 1220 & 1200 & $1200-1250$ & 5 \\
\hline $\mathrm{Mn}$ & NA & 1000 & 57 & 30 & 44 & 37 & 35 & $30-57$ & 2 \\
\hline $\mathrm{Na}$ & NA & 350000 & 1064 & 684 & 656 & 740 & 758 & $656-1064$ & 5 \\
\hline $\mathrm{Zn}$ & NA & 950 & 27 & 29 & 31 & 27 & 29 & $27-31$ & 2 \\
\hline $\mathrm{P}$ & NA & 55000 & 1070 & 1400 & 1170 & 1170 & 1110 & $1070-1400$ & 2 \\
\hline S & NA & NA & 620 & 700 & 630 & 630 & 560 & $620-700$ & 2 \\
\hline $\mathrm{Si}$ & NA & NA & 4350 & 1590 & 2210 & 2560 & 2350 & $1590-4350$ & 2 \\
\hline $\mathrm{Cl}$ & NA & 540000 & 2960 & 2180 & 2450 & 2270 & 2420 & $2180-2960$ & 5 \\
\hline
\end{tabular}

AYUSH: Ayurveda, Yoga \& Naturopathy, Unani, Siddha and Homeopathy ; CEC: Commission of the European Communities, UL: upper intake level, NA: not available, LLD: lower limit of detection, PDE: permitted daily exposure 
Table 2. Comparison of elemental concentrations ( $\mathrm{mg} / \mathrm{kg}$ ) by WD-XRF technique with published ICP-MS data

\begin{tabular}{|c|c|c|c|c|c|c|c|c|c|c|c|c|}
\hline \multirow{2}{*}{$\begin{array}{l}\text { Element } \\
(\mathrm{mg} / \mathrm{kg})\end{array}$} & \multicolumn{4}{|c|}{ TPC1 } & \multicolumn{4}{|c|}{ TPC2 } & \multicolumn{4}{|c|}{ TPC3 } \\
\hline & XRF & $\mathrm{ICP}^{*}$ & SD & RSD & XRF & $\mathrm{ICP}^{*}$ & $\mathrm{SD}$ & RSD & XRF & $\mathrm{ICP}^{*}$ & $\mathrm{SD}$ & RSD \\
\hline $\mathrm{Ba}$ & 24 & 16.8 & 5 & 25 & 20 & 14.8 & 4 & 21 & 20 & 15.2 & 3 & 19 \\
\hline $\mathrm{Cr}$ & 2 & 2.7 & 1 & 22 & 3 & 5.1 & 1 & 36 & 2 & 1.3 & 0 & 28 \\
\hline $\mathrm{Cu}$ & 5 & 7.5 & 2 & 28 & 7 & 6.0 & 1 & 11 & 6 & 4.3 & 1 & 23 \\
\hline $\mathrm{Zn}$ & 27 & 16.1 & 8 & 36 & 29 & 16.2 & 9 & 40 & 31 & 19.6 & 8 & 32 \\
\hline $\mathrm{Mn}$ & 57 & 45.2 & 8 & 16 & 30 & 22.8 & 5 & 19 & 44 & 32.9 & 8 & 20 \\
\hline $\mathrm{Fe}$ & 1329 & 1026 & 214 & 18 & 465 & 357 & 77 & 19 & 792 & 668 & 87 & 12 \\
\hline $\mathrm{Na}$ & 1064 & 762 & 213 & 23 & 684 & 490 & 137 & 23 & 656 & 456 & 141 & 25 \\
\hline $\mathrm{K}$ & 14760 & 12930 & 1294 & 9 & 13180 & 11057 & 1501 & 12 & 14560 & 13230 & 940 & 7 \\
\hline $\mathrm{Mg}$ & 1250 & 998 & 178 & 16 & 1220 & 960 & 184 & 17 & 1210 & 987 & 158 & 14 \\
\hline $\mathrm{Ca}$ & 2930 & 2536 & 279 & 10 & 3000 & 2672 & 232 & 8 & 3030 & 2721 & 218 & 8 \\
\hline
\end{tabular}

Table 2. contd.

\begin{tabular}{ccccccccc}
\hline \multicolumn{2}{c}{ TPC4 } & \multicolumn{7}{c}{ TPC5 } \\
XRF & ICP* & SD & RSD & XRF & ICP* & SD & RSD & RSD Range \\
21 & 16.1 & 3 & 19 & 20 & 14.2 & 4 & 24 & $19-25$ \\
2 & 3.8 & 1 & 45 & 1 & 2.1 & 1 & 50 & $22-50$ \\
5 & 5.2 & 0 & 3 & 5 & 4.2 & 1 & 12 & $3-23$ \\
27 & 16.5 & 7 & 34 & 29 & 17.1 & 8 & 37 & $32-40$ \\
37 & 29.2 & 6 & 17 & 35 & 27.6 & 5 & 17 & $16-20$ \\
869 & 711 & 111 & 14 & 918 & 730 & 133 & 16 & $12-19$ \\
740 & 541 & 141 & 22 & 758 & 529 & 162 & 25 & $22-25$ \\
15130 & 14220 & 643 & 4 & 13330 & 12480 & 601 & 5 & $4-12$ \\
1220 & 988 & 164 & 15 & 1200 & 948 & 178 & 17 & $8-10$ \\
2130 & 1888 & 171 & 9 & 3110 & 2729 & 269 & 9 & \\
\hline
\end{tabular}

${ }^{*}$ published data $;$ SD: standard deviation; $R S D$ : relative standard deviation

centrations i.e. low values were noticed by ICP-MS method 3 with respect to XRF data, may be due to multi-elemental standards, different sample extraction procedures and various dilution concentrations are part of ICP analysis whereas XRF is a non-destructive technique. In hypothesis, a specific digestion method only recovers certain elements absolutely that are easily soluble and not structurally complicated, especially present in plant materials. In the opposite case, technique XRF also suffers from significant matrix effects present in plant materials. However, the XRF technique penetrates deeper into the sample bonds than the chemical extraction procedure for ICP-MS, may be showing higher concentrations for the same sample.

\section{CONCLUSION}

$\mathrm{XRF}$ is a non-destructive sample technique and the results obtained by WD-XRF spectrometry in present study were found to be compatible with reported ICP-MS data which suggests that the XRF technique can be a good choice for estimation of elemental concentrations in plant / herbal / Ayurvedic samples.

\section{ACKNOWLEDGEMENT}

The authors express their gratitude to the Vice Chancellor of GITAM University, Visakhapatnam, for encouragement and facilitating necessary congenial environment to carry out research work. Also, the authors thank the Head, Laboratory X-ray Crystallography, Indian Institute of Chemical Technology (CSIR), Hyderabad, India, for extending their constant support.

\section{CONFLICT OF INTEREST}

The authors have declared that there is no conflict of interests.

\section{ABBREVIATIONS USED}

WD-XRF: Wavelength Dispersive X-ray Fluorescence Spectrometry; ICP-MS: Inductively Coupled Plasma Mass Spectrometry; AAS: Atomic Absorption Spectroscopy; PDE: Permitted Daily Exposure; UL: Upperintake Level; mg/kg: milligram/kilogram; WHO: World Health Organization; CEC: Commission of the European Communities; USP: United State Pharmacopeial Convention; SD: standard deviation; RSD: relative standard deviation; TPC: Triphala churna; ISM: Indian System of Medicine AFI: Ayurvedic Formulary of India

\section{REFERENCES}

1. Kantamreddi VSS, Wright CW. Screening Indian plant species for antiplasmodial properties - Ethnopharmacological compared with random selection. Phytother Res. 2012;26 (12):1793-9. 
2. WHO. Quality control methods for medicinal plant material. Geneva, 1998.

3. Kantamreddi VS, Veni VT, Malasani MK, Simhachalam B. Differentiation of Five Commercially Available Triphala churnas of an Ayurvedic Formulation by Elemental Fingerprint. Pharmacogn J. 2017;9 (1):117-2.

4. Swamy GY, Sivanarayanan P. Quantitative determination of essential and trace elements in Indian Ayurvedic medicinal herbs by WD-XRF spectrometry. Int $J$ Ayu Pharm Chem. 2014; 1(1): 52-62.

5. WHO. Quality control methods for medicinal plant material. Geneva. 1998 Last accessed on 2 January 2016. http://apps.who.int/iris/bitstream/10665/ 41986/1/9241545100.pdf

6. CEC. Nutrients and energy intakes for the European Community: Reports of the scientific committee for food (31st series). Luxembourg: Directorate-General Telecommunication, Information Industries and Innovation. 1993. Last accessed on 2 January 2016. http://ec.europa.eu/food/fs/sc/scf/out89.pdf

7. Marschner H. Mineral nutrition of higher plants. London: Oxford University Press. 1995

8. WHO. Barium in Drinking-water: Background document for development of
WHO Guidelines for Drinking-water Quality. File WHO/SDEMSH/03.04/76. Geneva. 2004. Last accessed on 2 January 2016. http://www.who.int/water_ sanitation health/dwq/chemicals/barium.pd

9. USP. General Chapter on Inorganic Impurities: Heavy Metals. USP Workshop on "Metal Impurities in Drugs and Dietary Supplements: Digest of Comments Received on the PF 34(5) Heavy Metals Stimuli Article. 2009. Last accessed on 2 January 2016. http://www.usp.org/sites/default/files/usp_pdf/EN/USPNF/ key-issues/2009-04-22MetallmpuritiesCommentDigest.pdf

10. Pednekar PA, Raman B. Multielement determination in methanolic soxhlet leaf extract of Semecarpus anacardium (linn.f.) by ICP-AES technique. Asian Journal of Pharmaceutical and Clinical Research 2013; 6 (3):132-7.

11. Inam F, Deo S, Mahashabde R, Kadam N, Chopra G. Comparative account of heavy metal analysis of selected plant species by XRF scanning. Journal of Materials Science and Engineering 2011; A1: 658-61.

12. Canfield RL, Henderson JrCR, Cory-Slechta DA, Cox C, Jusko TA, Lanphear BP. Intellectual impairment in children with blood lead concentrations below $10 \mathrm{\mu g}$ per deciliter. New England Journal of Medicine 2003; 348 (16):1517-26

\section{GRAPHICAL ABSTRACT}

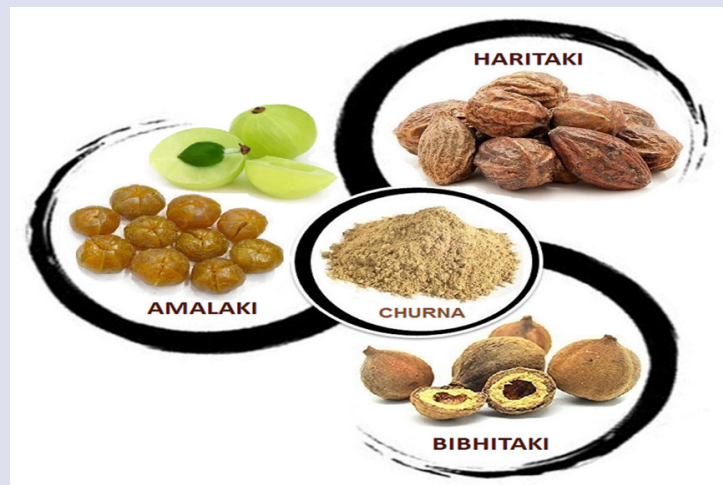

\section{SUMMARY}

- Triphala churna is one of the well known powder preparations of ISM being used in Ayurveda since ancient time. As per AFI, it is a polyherbal preparation comprised of 3 dried fruits viz. Haritaki (Terminalia chebula Gaertn Retz.), Bibhitaki (Terminalia bellirica Roxb.) and Amalaki (Embellica officinalis Gaertn.), in equal proportions $(1: 1: 1)$.

- Elemental analysis in the present study has significance with respect to WDXRF technique. The levels of 19 elemental concentrations $(\mathrm{mg} / \mathrm{kg})$ in 5 different branded TPC drugs have been found in a range of $1(\mathrm{Cr})$ to $15130(\mathrm{~K})$ and a nonessential element, $\mathrm{Pb}(41-46 \mathrm{mg} / \mathrm{kg}$ ) was found above its PDE limit ( $\leq 10 \mathrm{mg} / \mathrm{kg})$.

- Good agreements were achieved between WD-XRF values and ICP-MS data.

- Results show that WD-XRF technique can be a good choice to estimate elemental concentrations in herbal drugs

\section{ABOUT AUTHORS}

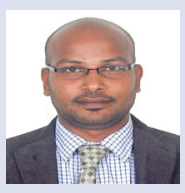

Venkata S. S. Kantamreddi, Chemist, received his PhD in Chemistry from University of Bradford, United Kingdom under Commonwealth Scholarship. He has sixteen years of professional experience including teaching, research and industry. Expertise in isolation and structural elucidation of natural products, quantifications of bio-active markers, standardization of herbal drugs and in-vitro antiplasmodial screenings. His area of research interest is to develop potent antimalarials. He is currently working as an Assistant Professor of Chemistry at GITAM University, Visakhapatnam, India.

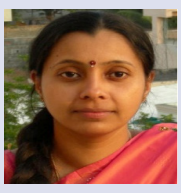

Veni V.T., having 15 years of professional experience in teaching, research and industry and obtained her M.Sc. in Bio-inorganic chemistry (1995) and M.Phil. in Chemistry (1997) from Andhra University, Visakhapatnam, India. At present, she is pursuing Ph.D. at GITAM University, Visakhapatnam. Her doctoral research is focused on the quality control of herbal drugs.

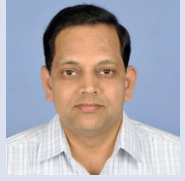

Swamy G.Y.S.K., Principal Technical Officer at Laboratory of X-ray Crystallography, Indian Institute of Chemical Technology, CSIR, Hyderabad, India. He was a Postdoctoral fellow (2001-03) of Colorado State University, USA and received his Ph.D. (1999) from Osmania University, Hyderabad and M.Sc. (1988) from JNTU, Hyderabad. Studies on drug polymorphism using powder and single crystal X-ray crystallography and characterization of herbo-metallic products using X-ray fluorescence spectroscopy (XRF) are his current research activities.

Cite this article: Kantamreddi VSS, VeniVT, Swamy GYSK. A Quantitative Approach to Estimate both Essential and Non-essential Elements in Some Commercia Samples of Triphala churna by using WD-XRF Spectrometry. Pharmacogn J. 2017;9(3):378-81 